\title{
The clone selection studies on Siyah Gemre grape variety
}

\author{
Yıldız Dilli ${ }^{1}$, Adem Yağcs ${ }^{2}$, Fadime Ateş ${ }^{1}$, and Naci Yıldız ${ }^{1}$ \\ ${ }^{1}$ Viticulture Research Station, Manisa, Turkey \\ ${ }^{2}$ Department of Horticulture, Faculty of Agriculture, University of Gaziosmanpaşa, Tokat, Turkey
}

\begin{abstract}
V. vinifera L.cv. "Siyah Gemre" is an important table grape variety of Mediterranean Region in Turkey. It is late season, medium bunch density, round berry, red-black colored and seeded. The study was carried out to make clone selection for increasing the yield and quality in "Siyah Gemre" grape variety The project was completed in two stages. First one was selection nominees of mother clone vine and second was establishing of clonal collection vineyard. The first stage studies were carried out at grower vineyards of İsparta, Turkey surroundings where "Siyah Gemre" is grown wide spread, between 2001 and 2003. Clonal nominees were selected by using counting the cluster and shoot at the end of the project. After that, the clonal collection vineyard was established with spacing $3.0 \mathrm{~m} \times 1.65 \mathrm{~m}$ in 2004 . Twelve vines of each clonal nominees were grafted onto $110 \mathrm{R}$ rootstock. In the study the values of yield, number of cluster, weight of cluster, 100 berry weight, index of maturity, sensory analysis, weight of pruning and bud productivity were evaluated between 2007-2012. At the end of this study, according to the values of total point, five clone nominees were selected and among their 3, 19, 24 numbered clones were chosen in terms of total sensory analysis score, yield and stability, cluster and berry properties respectively.
\end{abstract}

\section{Introduction}

Grape varieties that has a great potential in Turkey, owing to the fact that Anatolia is one of the centers of diversity for V. vinifera [1]. In the methods used in vine breeding studies is the largest rate, clone selection method. This is followed by cross breeding, gene transfer and mutation breeding methods [2]. The purpose of the clonal selection method in viticulture is to choose superior types taking advantage of the differences that exist within a variety. These differences occur environmental conditions, mutations, that they have come from different origins of clones from reasons such as virus infections [3].

The clonal selection process consists in prospecting clones in the field, studying their agronomic and enological performances, sanitary state, and varietal identity. The healthy and more interesting clones are then selected attempting to maintain intravariability as far as possible. These clones are planted under homogeneous conditions to study their capacity to produce a quality grape with the aim of certifying and subsequently distributing these clones to grape growers [4].

Siyah Gemre grape variety is grown extensively around İsparta province in Mediterranean Region and consumed mostly as table grapes. Subject of this study was selection of "Siyah Gemre" grapevine with high yield, stability and quality characteristics (large berry, low density, etc.).

\section{Materials and methods}

Siyah Gemre grape variety is late season, medium bunch density, round berry, red-black colored and seeded [5].
Study was carried out at grower vineyards of İsparta, Turkey surroundings where "Siyah Gemre" is grown wide spread.

In order to evaluate, Siyah Gemre grapevines were collected from vines of İsparta province. During the stage of selection nominees of mother clone vine, average cluster and shoot numbers had been determined. Macroscopic observations for virus diseases and elimination of infected vines had been made. The vines above average values and healthy ones were marked. Superior vines depending on cluster/shoot ratio, growth and evaluation of data for quality characters were selected in 2001-2003. The clon collection vineyard in Manisa Viticulture Research Station was established with selected 33 clonal nominees in 2004. Experimental vineyard was established with spacing $3.0 \mathrm{~m} \times 1.65 \mathrm{~m}$ and on grafted 110R rootstock which was determined according to soil analysis. In the study, there are twelve vines from each clone candidate.

Over a four-year period, It was obtained the values of the yield-per-vine $(\mathrm{kg})$, number of cluster-per-vine, the weight of cluster $(\mathrm{g})$, the weight of berry $(\mathrm{g})$, soluble solid $(\%)$, titratable acidity $(\mathrm{g} / \mathrm{L})$ (tartaric acid equivalent), index of maturity, the pruning weight ( $\mathrm{kg} / \mathrm{vine})$ and bud productivity. For titratable acidity, $10 \mathrm{ml}$ of diluted samples were titrated with $0.1 \mathrm{~N} \mathrm{NaOH}$ to an end point of $\mathrm{pH} 8.1$ [6] and was converted to tartaric acid equivalents.

Clones were evaluated over $0-5$ points in each of sensory properties by 10 experters and sensory test scoring criteria and definitions used as Table 1.

In the evaluation of four years data to determine the most highly qualified among 33 clones nominees belong to Siyah Gemre grape variety, researchers suggested 
Table 1. Sensory test scoring criteria.

\begin{tabular}{|l|c|}
\hline \multicolumn{1}{|c|}{ Characteristics } & Class interval scores \\
\hline General appearance of cluster & $0-5$ \\
\hline $\begin{array}{l}\text { Berry: uniformity of shape, skin } \\
\text { colour and and size }\end{array}$ & $0-5$ \\
\hline Taste and flavour & $0-5$ \\
\hline $\begin{array}{l}\text { Thickness of skin, berry flesh } \\
\text { properties and seed sizes }\end{array}$ & $0-5$ \\
\hline Total Score & 20 \\
\hline
\end{tabular}

Table 2. The parameters taken into account in the evaluation according to the weighted-rankit method and relative scores.

\begin{tabular}{|l|l|c|}
\multicolumn{1}{|c|}{ Parameters } & \multicolumn{1}{c|}{ Unit } & Relative scores \\
\hline Yield & $\mathrm{kg} / \mathrm{da}$ & 40 \\
\hline Pruning weight & $\mathrm{kg} / \mathrm{vine}$ & 10 \\
\hline Cluster weight & $\mathrm{g}$ & 10 \\
\hline Berry weight & $\mathrm{g}$ & 15 \\
\hline Index of maturity & - & 5 \\
\hline Sensory tasting score & $0-20$ & 20 \\
\hline
\end{tabular}

weighted-rankit method was used [7]. The parameters considered in the evaluation and their projected relative scores are shown in Table 2. In the study, average values of four years for all clones for each parameter, divided into five classes according to size values (very low, low, moderate, high, very high) and among $2-10$ points are given to this class. In the calculation of weighted-rankit score belongs to the parameter of clones, value obtained by multiplying the class scores with the relative score is based on 6 parameters that mentioned for table grapes of weighted-rankit scores collected and total weighted-rankit score belong to the clones was obtained.

\section{Results and discussion}

Siyah Gemre variety was evaluated suitable for homogen grape skin colour and good bunch and berry structures for table consumption and it was determined good for table consumption for late time harvest in the beginning of October in İsparta province of Turkey. In the study hopeful phenolic results were determined. All phenolic compounds were determined in different ratios for Siyah Gemre grape variety. Highest values for Siyah Gemre variety were evaluated from gallic acid, epigallokatechin, epigallokatechin3-gallate and resveratrol [9].

According to weighted-rankit methods the first four clone candidates in Table 3 , findings of clone candidates are shown in Table 4. Regarding the results of this evaluation which are essential to clone selection, the highest
Table 3. The first four ranks the clone candidates in terms of weighted-rankit parameters.

\begin{tabular}{|l|c|c|c|c|c|}
\hline Parameters & $\begin{array}{c}\text { Relative } \\
\text { scores }(\mathbf{\%})\end{array}$ & $\mathbf{1}$ & $\mathbf{2}$ & $\mathbf{3}$ & $\mathbf{4}$ \\
\hline Yield & 40 & G-19 & G-17 & G-29 & G-24 \\
\hline $\begin{array}{l}\text { Pruning } \\
\text { weight }\end{array}$ & 10 & G-01 & G-05 & G-04 & G-02 \\
\hline $\begin{array}{l}\text { Cluster } \\
\text { weight }\end{array}$ & 10 & G-19 & G-32 & G-23 & G-12 \\
\hline $\begin{array}{l}\text { Berry } \\
\text { weight }\end{array}$ & 15 & G-24 & G-18 & G-19 & G-08 \\
\hline $\begin{array}{l}\text { Index of } \\
\text { maturity }\end{array}$ & 5 & G-13 & G-18 & G-14 & G-33 \\
\hline $\begin{array}{l}\text { Sensory } \\
\text { tasting } \\
\text { score }\end{array}$ & 20 & G-03 & G-18 & G-20 & G-19 \\
\hline $\begin{array}{l}\text { RANKING } \\
\text { TO TOTAL } \\
\text { SCORE }\end{array}$ & & G-19 & G-15 & G-24 & G-17 \\
\hline
\end{tabular}

score (920 points) took G-19 No. candidate. The second candidate G-15 No. (830 scores), the third candidate G-24 No. (810 scores) took.

Ripening time of clones was determined to index of maturity. Although cluster weight, berry weight and Index of maturity had been considered as an indicator of quality; scores of sensory analyses were influential [8]. The G-03 clone with 650 score, in respect to this the highest average sensory analysis value (14.45) came to the fore.

\section{Conclusions}

The evaluation of product obtained 33 clonal nominees in the clone selection vineyard, was made emphasizing yield, growth and table quality parameters in 2007-2012 years. Macroscopic observations for virus diseases and elimination of infected vines had been made at the first stage of this study.

In any of vine as growth, yield and quality have not seen to a problem any symptom and was continued with all the clone candidates.

Siyah Gemre variety primarily in the selection of clones will be recommended to be grown in Isparta conditions; total scores as a result of the weighted-rankit performed over the six parameters in Table 4 is based on.

According to the results the said evaluation, 19, 15, 24 and 17 No. candidates taking first four among the studied 33 clone candidates as well as the 3 No. candidate in respect to the highest average score of sensory analysis has been found appropriate to selected as clones.

Superior clones were selected according to a special scoring system for yield, growth and quality parameters of table grapes additional to variance analysis results. 
Table 4. The results of the clone candidates weighted-rankit.

\begin{tabular}{|c|c|c|c|c|c|c|c|c|c|c|c|c|c|c|}
\hline \multirow[t]{2}{*}{$\begin{array}{c}\text { Clone } \\
\text { candidates }\end{array}$} & \multicolumn{2}{|c|}{$\begin{array}{l}\text { Yield (kg/ } \\
\text { vine) }\end{array}$} & \multicolumn{2}{|c|}{$\begin{array}{c}\text { Pruning } \\
\text { weight } \\
\text { (g/vine) }\end{array}$} & \multicolumn{2}{|c|}{$\begin{array}{c}\text { Cluster } \\
\text { weight (g) }\end{array}$} & \multicolumn{2}{|c|}{$\begin{array}{c}\text { Berry } \\
\text { weight }(g)\end{array}$} & \multicolumn{2}{|c|}{$\begin{array}{l}\text { Index of } \\
\text { maturity }\end{array}$} & \multicolumn{2}{|c|}{$\begin{array}{c}\text { Sensory } \\
\text { Analysis } \\
(0-20)\end{array}$} & \multirow[t]{2}{*}{$\begin{array}{l}\text { Total } \\
\text { score }\end{array}$} & \multirow[t]{2}{*}{ Row } \\
\hline & Mean $^{1}$ & Score & Mean $^{1}$ & Score & Mean $^{1}$ & Score & Mean $^{1}$ & Score & Mean $^{1}$ & Score & Mean $^{1}$ & Score & & \\
\hline G-01 & 12.68 & 320 & 4424 & 100 & 401 & 60 & 3.8 & 90 & 35 & 30 & 12.18 & 80 & 680 & 16 \\
\hline G-02 & 10.93 & 240 & 3639 & 80 & 403 & 60 & 3.3 & 60 & 32 & 20 & 11.30 & 40 & 500 & 28 \\
\hline$G-03$ & 9.20 & 160 & 3472 & 80 & 415 & 60 & 3.8 & 120 & 35 & 30 & 14.45 & 200 & 650 & 18 \\
\hline G-04 & 10.45 & 160 & 3833 & 80 & 409 & 60 & 3.6 & 90 & 32 & 20 & 11.55 & 40 & 450 & 30 \\
\hline G-05 & 12.61 & 320 & 4056 & 100 & 429 & 60 & 3.9 & 120 & 33 & 20 & 13.36 & 160 & 780 & 6 \\
\hline G-06 & 10.46 & 160 & 2681 & 40 & 383 & 60 & 3.6 & 90 & 30 & 10 & 13.19 & 160 & 520 & 26 \\
\hline G-07 & 9.47 & 160 & 3583 & 80 & 358 & 40 & 3.6 & 90 & 32 & 20 & 12.63 & 120 & 510 & 27 \\
\hline G-08 & 9.97 & 160 & 2486 & 40 & 462 & 80 & 4.3 & 150 & 36 & 30 & 13.48 & 160 & 620 & 21 \\
\hline G-09 & 10.14 & 160 & 3319 & 60 & 353 & 40 & 3.6 & 90 & 31 & 10 & 11.53 & 40 & 400 & 31 \\
\hline G-10 & 10.10 & 160 & 3472 & 80 & 456 & 80 & 4.1 & 120 & 31 & 10 & 12.86 & 120 & 570 & 25 \\
\hline G-11 & 12.72 & 320 & 2694 & 40 & 387 & 60 & 3.7 & 90 & 36 & 40 & 12.90 & 120 & 670 & 17 \\
\hline G-12 & 11.69 & 240 & 3139 & 60 & 477 & 80 & 4.0 & 120 & 36 & 40 & 13.46 & 160 & 700 & 14 \\
\hline G-13 & 13.16 & 320 & 3083 & 60 & 430 & 60 & 4.1 & 120 & 40 & 50 & 12.52 & 80 & 690 & 15 \\
\hline G-14 & 7.28 & 80 & 3133 & 60 & 258 & 20 & 2.8 & 30 & 39 & 50 & 11.99 & 80 & 320 & 33 \\
\hline$G-15$ & 14.09 & 400 & 3167 & 60 & 472 & 80 & 4.2 & 150 & 33 & 20 & 12.96 & 120 & 830 & 2 \\
\hline G-16 & 12.55 & 320 & 2444 & 20 & 370 & 40 & 3.7 & 90 & 34 & 30 & 13.08 & 120 & 620 & 22 \\
\hline$G-17$ & 15.48 & 400 & 2958 & 60 & 470 & 80 & 4.0 & 120 & 32 & 20 & 12.93 & 120 & 800 & 4 \\
\hline G-18 & 10.92 & 240 & 1972 & 20 & 424 & 60 & 4.4 & 150 & 38 & 50 & 14.35 & 200 & 720 & 11 \\
\hline$G-19$ & 15.77 & 400 & 2944 & 40 & 552 & 100 & 4.3 & 150 & 35 & 30 & 14.05 & 200 & 920 & 1 \\
\hline G-20 & 11.96 & 240 & 3542 & 80 & 413 & 60 & 3.9 & 120 & 34 & 30 & 14.12 & 200 & 730 & 10 \\
\hline G-21 & 9.58 & 160 & 2928 & 40 & 370 & 40 & 3.5 & 90 & 32 & 20 & 11.67 & 40 & 390 & 32 \\
\hline G-22 & 12.91 & 320 & 2611 & 40 & 417 & 60 & 4.2 & 150 & 32 & 20 & 12.75 & 120 & 710 & 12 \\
\hline G-23 & 14.51 & 400 & 2458 & 20 & 479 & 80 & 3.8 & 120 & 33 & 20 & 12.90 & 120 & 760 & 7 \\
\hline$G-24$ & 14.86 & 400 & 2778 & 40 & 475 & 80 & 4.4 & 150 & 34 & 20 & 12.86 & 120 & 810 & 3 \\
\hline G-25 & 11.88 & 240 & 3126 & 60 & 471 & 80 & 3.9 & 120 & 34 & 20 & 12.14 & 80 & 600 & 23 \\
\hline G-26 & 10.32 & 160 & 2222 & 20 & 323 & 40 & 3.6 & 90 & 35 & 30 & 13.01 & 120 & 460 & 29 \\
\hline G-27 & 13.90 & 320 & 2972 & 60 & 394 & 60 & 3.7 & 90 & 35 & 30 & 12.45 & 80 & 640 & 19 \\
\hline G-28 & 12.48 & 320 & 2667 & 40 & 442 & 80 & 3.8 & 120 & 35 & 30 & 12.69 & 120 & 710 & 13 \\
\hline G-29 & 15.40 & 400 & 3208 & 60 & 441 & 80 & 3.9 & 120 & 33 & 20 & 12.92 & 120 & 800 & 5 \\
\hline G-30 & 11.88 & 240 & 3243 & 60 & 439 & 80 & 4.2 & 150 & 35 & 30 & 12.29 & 80 & 640 & 20 \\
\hline G-31 & 13.17 & 320 & 2944 & 40 & 387 & 60 & 3.9 & 120 & 31 & 10 & 11.87 & 40 & 590 & 24 \\
\hline G-32 & 13.72 & 320 & 2431 & 20 & 502 & 100 & 4.2 & 150 & 37 & 40 & 13.18 & 120 & 750 & 9 \\
\hline G-33 & 13.30 & 320 & 2611 & 40 & 459 & 80 & 4.0 & 120 & 36 & 40 & 13.45 & 160 & 760 & 8 \\
\hline
\end{tabular}

${ }^{1}$ Average value of the clone.

\section{References}

[1] Arroyo-Garcia, R., L. Ruiz-Garcia, L. Boulling, R. Ocete, M. A. López, C. Arnold, A. Ergul, G. Söylemezoğlu, H. İ. Uzun, F. Cabello, J. Ibáñez, M. K. Aradhya, A. Atanassov, I. Atanassov, S. Balint, J. L. Cenis, L. Costantini, S. Gorislavets, M. S. Grando, B. Y. Klein, P. McGovern, D. Merdinoglu, I. Pejic, F. Pelsy, N. Primikirios, V. Risovannaya,
K. A. Roubelakis-Angelakis, H. Snouss, P. Sotiri, S. Tamhankar, P. This, L. Troshin, J. M. Malpica, F. Lefort, and J. M. Martinez-Zapater., Genetic Evidence for The Existence of İndependent Domestication Events İn Grapevine. Molecular Ecology, 15(12), 3707-3714 (2006).

[2] Sabir, A., Tangolar, S., Aims and Methods of Grape Breeding Researches Carried out Worldwide Recently. Alatarım, 5 (2): 9-16 (2006). 
[3] Kader, S., Yılmaz, N., Ilgın C.,. The Clon Selection Studies On Çal Karası Grape Variety. Ministry of Agriculture and Rural Affairs General Directorate of Agricultural Research and Policy. Manisa Viticulture Research Institute, Publication No: 103, Turkey (2004).

[4] Loureiro M.D., Moreno-Sanz P., Suarez B., Clonal preselection of grapevine cultivars of the appellation "Cangas Quality Wine" (Asturias, Spain). Hort. Sci. (Prague), 38: 71-80 (2011).

[5] Ecevit, M.F., Kelen, M., Determination of Ampelographical Characters of Grape Cultivars Grown in Isparta (Atabey). Tr. J. of Agriculture and Forestry, 23 (1999) 511-518.

[6] Cemeroğlu, B., Basic Analysis Methods in Fruit and Vegetable Processing Industry. BILTA University Book Series: 02-2, Ankara, 381-250 (1992).
[7] Ayfer, M., Çelik, M., Akça, Ankara ve Williams Armut Çeşitleri ile S.Ö. Ayva Anaçlarının Uyuşumları Üzerinde Araçtırmalar, Tübitak VI. Bilim Kongresi, TOAG Tebliğleri Bahçe Bitkileri Seleksiyonu, (1977), 111-112.

[8] Kirac1, M. A., Özer, C., Clone Selection Studies on Important Table Grape Varieties of Marmara Region of Turkey, 35th World Congress of Vine and Wine, June $18^{\text {th }}-22^{\text {th }}$ İzmir-Turkey (2012).

[9] Gargın, S., Researchs on Some Grape Varieties of Eğirdir Region for Ampelographic-Moleculer Identification and Determination of Phenolic Compositions Yield and Quality Traits Doctoral Thesis, Ege Üniversity, 195 p. (2014). 